\title{
MECANISMOS DE REPARO AOS DANOS NO DNA NOS PONTOS DE CHECAGEM DO CICLO CELULAR
}

\section{Leandro Lopes Nepomuceno", Jorge Luís Ferreira², Vanessa de Sousa Cruz ${ }^{3}$,} Gabriela Hadler Gabriel ${ }^{1}$, Eugênio Gonçalves de Araújo ${ }^{4}$

${ }^{1}$ Doutorando pelo programa de Pós-Graduação em Ciência Animal, Departamento de Patologia, Laboratório Multiusuário de Cultivo Celular - EVZ/UFG, Goiânia, GO (leandro_lopes795@hotmail.com)

${ }^{2}$ Prof. Dr. Associado I do Curso de Medicina Veterinária do Campus de Araguaína, Núcleo Avançado de estudos, Pesquisa e Extensão em Melhoramento Genético de

Zebuínos (Napgem) - EMVZ/UFT, Araguaína, TO

${ }^{3}$ Prof ${ }^{a}$. Dra. da Universidade Federal de Goiás, Departamento de Patologia, Laboratório Multiusuário de Cultivo Celular - EVZ/UFG, Goiânia, GO

${ }^{4}$ Prof. Dr. Titular da Universidade Federal de Goiás, Departamento de Patologia, Laboratório Multiusuário de Cultivo Celular - EVZ/UFG, Goiânia, GO

Recebido em: 08/04/2017 - Aprovado em: 10/06/2017 - Publicado em: 20/06/2017 DOI: 10.18677/EnciBio_2017A71

Frente aos avanços tecnológicos e no conhecimento, o entendimento dos mecanismos envolvidos na divisão celular e os diferentes fatores que controlam as fases do ciclo celular vêm ganhando destaque e uma nova compreensão a nível molecular. Ademais, compreender a interação complexa e diafonia entre os diferentes mecanismos de regulação com sobreposição e interação entre diferentes rotas, que competem ou colaboram para reparar um mesmo processo de injúria, conferem a reparação precisa dos danos exercidos ao DNA, processo de suma importância para a integridade do genoma. Em pretexto, esta revisão teve por objetivo descrever os mecanismos mais importantes que ocorrem em resposta aos danos do DNA de uma célula eucariótica, discutir a sua atividade através do ciclo celular e elucidar os principais mecanismos de regulação que influenciam na escolha das vias de reparação.

PALAVRAS-CHAVE: Biologia Molecular; Divisão Celular; Neoplasia.

\section{REPAIR MECHANISMS TO DNA DAMAGES IN THE CELL CYCLE CHECKPOINTS}

\begin{abstract}
Due to the advances in technology and in knowledge, the understanding of the mechanisms involved in cell division and the different factors that control the phases of cell cycle are gaining prominence and a new uptake in a molecular level. In addition, understand the crosstalk between the different mechanisms of regulation with overlapping and interaction between different routes, which compete or collaborate to repair the same injury process, is necessary to ensure the precise repair of damages in DNA, a process that is very important to the maintance of the integrity of the genome. In this way, this review aimed to describe the most important mechanisms that occur in response to damage in the DNA of a eukaryotic cell, to
\end{abstract}


discuss its activity through the cell cycle and to elucidate the main regulatory mechanisms that influence the choice of repair pathways.

KEYWORDS: Molecular Biology; Cell Division; Neoplasm.

\section{INTRODUÇÃO}

A renovação celular é dada a partir da duplicação de uma célula preexistente, o que representa o ciclo de vida de uma célula. O câncer é uma doença eminentemente genética, pois uma célula tumoral apresenta alterações somáticas no DNA, o que acarreta em divisões celulares autônomas e irrestritas. Esse fato pode ser considerado um produto de mau funcionamento na regulação do ciclo celular, de tal modo que as células defeituosas apresentam maior facilidade de proliferação e sequestro de nutrientes em comparação a outras células normais, além de ocuparem o lugar do tecido integro (LING et al., 2010).

Existem mudanças metabólicas e estruturais necessárias para que uma célula apresente uma morfologia tipicamente oncótica. Os fatores que mais influenciam essas alterações são as mutações acumuladas a cada divisão celular, resultantes da exposição a agentes deletérios, que promovem alterações no DNA e contribuem para a manifestação das características oncóticas (BARREIRO-ALONSO et al., 2015).

Os genes que são modificados em uma célula tumoral estão envolvidos diretamente ou indiretamente no controle do ciclo celular em suas diferentes fases, a saber: gap $0\left(\mathrm{G}_{0}\right)$, gap $1\left(\mathrm{G}_{1}\right)$, síntese $(\mathrm{S})$, gap $2\left(\mathrm{G}_{2}\right)$ e mitose $(\mathrm{M})$. O ciclo celular é permeado por vários mecanismos de controle, com proteínas e mecanismos que constantemente identificam a integridade e a capacidade celular em prosseguir na mitose (THORENOOR et al., 2016).

A mitose exerce importância distinta nos seres vivos unicelulares e pluricelulares. Nos últimos, a divisão celular tem o intuito de promover o crescimento do indivíduo, reparo do tecido vivo (regeneração) e reposição de células mortas. Já para os seres unicelulares, este tipo de divisão celular está relacionada diretamente com a reprodução da espécie, sendo um requisito primordial a transferência precisa da informação genética (FOLLAIN et al., 2016).

A divisão celular é um processo que avança de modo a coordenar o crescimento celular, visando a prevenção de uma ampliação inapropriada do material genético, o que ocasionaria a instabilidade no genoma (PIERRON, 2015). O genoma está constantemente sendo ameaçado por agentes exógenos que podem danificar o DNA, por meio de mecanismos como hidrólise das purinas e pirimidinas, danos induzidos por espécies reativas de oxigênio e nitrogênio, defeitos de replicação casuais que geram sequenciamentos incorretos, ou mesmo rupturas dos filamentos (ZHENG et al., 2014)

As lesões periódicas no DNA devem ser reparadas para evitar a perda ou a transmissão incorreta da informação genética. Tais erros podem causar anormalidades no desenvolvimento e tumorigênese (LOPEZ et al., 2014). No entanto, a escolha de qual sistema de reparação deverá ser usado depende tanto do tipo de lesão e em que fase do ciclo celular a célula se encontra (CECCALDI et al., 2016).

Uma quebra da dupla ligação do DNA em fases $S$ e $G_{2}$ é facilmente reparada por recombinação homóloga, utilizando a fita homologa intacta. No entanto, com o progresso do ciclo celular para fase $G_{2}$ e $M$, as cromatinas são condensadas em uma estrutura de cromossomo altamente ordenada, o que torna 
difícil a identificação do dano e o reparo do cromossomo pelo mesmo processo (SYAM et al., 2014; CECCALDI et al., 2016).

A coordenação da via de reparação de DNA e o ciclo celular são controladas por meio de diferentes proteínas do ciclo celular, tais como quinases dependentes de ciclina (CDKs). CDKs regulam as transições do ciclo celular por meio da indução da degradação de proteínas inibidoras do ciclo celular e são periodicamente ativadas por suas subunidades reguladoras, ciclinas, expressas por sua vez de forma diferente durante as fases do ciclo celular (BERTOLI et al., 2013).

Esta revisão teve por objetivo descrever os mecanismos de resposta aos danos do DNA mais importantes que operam em uma célula eucariótica, discutir a sua atividade através do ciclo celular e elucidar os principais mecanismos de regulação que influenciam a escolha das vias de reparação.

\section{CICLO CELULAR}

O ciclo celular é o processo pelo qual uma célula diploide (2n) dá origem a duas células idênticas. Contudo, podem haver diferenças geneticamente sutis, pois no momento da replicação, alguns nucleotídeos podem ser trocados e gerar uma sequência de DNA diferente da célula progenitora. Essas mudanças, no geral, não comprometem as funções celulares (NOUSPIKEL, 2013).

Há duas grandes fases na divisão celular, a interfase e a mitose. Após estudos mais pormenorizados, subdivisões foram adicionadas em cada etapa. A interfase contempla as fases $\mathrm{G}_{0}, \mathrm{G}_{1}, \mathrm{~S}$ e $\mathrm{G}_{2}$. A mitose é subdividida em Prófase, Metáfase, Anáfase, Telófase e Citocinese (DOMINGUEZ-BRAUER et al., 2015).

A fase $G_{0}$ compreende uma etapa em que as atividades metabólicas normais da célula encontram-se em plena carga. A partir do momento que a célula recebe estímulo mitógeno, tem-se o início da divisão celular e o avanço para a fase $\mathrm{G}_{1}$. Entretanto, o tempo de permanência da fase $\mathrm{G}_{0}$ varia muito de célula para célula, o que depende, em parte, do grau de complexidade e função celular (BLANPAIN \& SIMONS, 2013). Por exemplo, células epiteliais, do folículo capilar e linfócitos apresentam maior sensibilidade aos agentes químicos e físicos que afetam a replicação do DNA; dessa forma, a taxa mitótica dessas células é bastante expressiva, sendo necessária constante reposição dessas células no organismo. Em contrapartida, as células terminalmente diferenciadas, como o epitélio colunar do ápice da vilosidade intestinal, neurônios e as células cardíacas, permanecem em $\mathrm{G}_{0}$ indefinidamente (REDON et al., 2011; SPERKA et al., 2012; BLANPAIN \& SIMONS, 2013).

Os principais estímulos capazes de induzir a divisão celular são mediados pelo contato entre duas células (célula-célula), os quais influenciam o crescimento e a sobrevivência celular. Os mecanismos responsáveis por essa função são proteínas ligadas à superfície da membrana, à matriz intracelular ou mesmo proteínas secretadas pela própria célula (MAO et al., 2016).

A fase $G_{1}$ é o período em que a célula se prepara para a divisão celular. Para tal, o volume celular aumenta, as organelas são duplicadas e verifica-se a integridade do DNA. Este é o primeiro ponto de regulagem da divisão, conhecido como ponto de checagem $\mathrm{G}_{1}$. Caso haja dano ao DNA, proteínas responsáveis por ativar os mecanismos de reparo serão recrutadas; caso não seja detectado dano ao ácido nucléico, a célula segue para fase S (CHAUHAN et al., 2015).

A fase de Síntese é o período em que ocorre a replicação do material genético de forma semiconservativa. Ao término da divisão, o material genético das células filhas irá conter o mesmo número de cromossomos da célula progenitora. 
Nessa etapa, também pode ser evidenciado o início da duplicação dos centríolos e dos centrossomos (O'DONNELL et al., 2013).

A fase subsequente, $G_{2}$, é marcada pelo início da condensação dos cromossomos e pela migração dos centríolos e centrossomos para polos opostos. $A$ fase $\mathrm{G}_{2}$ apresenta uma particularidade no ciclo celular, pois nessa etapa é evidenciado o segundo ponto de regulagem do ciclo celular, ponto de checagem $\mathrm{G}_{2}$, com o intuito de verificar a completa replicação do DNA (CHAUDHARY et al., 2013).

Com o término de $\mathrm{G}_{2}$, a interfase finaliza e inicia-se a mitose propriamente dita. A mitose é a fase que compreende a divisão do núcleo celular e do citoplasma (Citocinese). Em comparação com a interfase, a fase $\mathrm{M}$ é extremamente curta, com duração aproximada de uma hora; entretanto, diversas modificações e acontecimentos importantes são representados em suas subfases (SAMWER et al., 2013).

A prófase é marcada pela degradação do envoltório nuclear, a carioteca, e do nucléolo. Com o término da migração dos centríolos e respectivos centrossomos, iniciada anteriormente na fase $\mathrm{G}_{2}$, os mesmos irradiam microtúbulos, compostos pela proteína filamentosa tubulina, que se fixam nos cromossomos próximos ao centrômero em uma região intitulada de cinetócoro. Esta aderência é importante para direcionar os cromossomos para a placa equatorial (VICENTE \& CANDE, 2014).

A metáfase tem início nesse período, com os cromossomos apresentando o máximo de condensação e localizados na placa equatorial. Esta etapa é o último ponto de regulagem do ciclo celular, conhecido como ponto de checagem M. Deste modo, caso os cromossomos não apresentem compactação completa, não se localizem na placa equatorial ou mesmo se as fibras do fuso não estiverem aderidas aos respectivos centrômeros, o ciclo celular é interrompido até que haja a correção do problema, o que permite assegurar que as novas células tenham a mesma quantidade de cromossomos (DE JESÚS RODRÍGUEZ-GÓMEZ \& FRÍASVÁZQUEZ, 2014). Partindo desse princípio, pode-se utilizar esse mecanismo em algumas técnicas laboratoriais para interromper a replicação da célula e estudar os cariótipos. Com a adição de colchicina, substância que evita a formação das fibras do fuso, Alves e Magalhães testaram e adequaram metodologias tradicionalmente empregadas em citogenética animal para a obtenção de metáfases mitóticas (ALVES \& MAGALHÃES, 2010).

A anáfase tem seu início com a segregação das cromátides irmãs e migração das organelas para polos opostos. Durante a telófase, surge o envoltório nuclear, a formação do nucléolo e início da descondensação das cromátides (TIANG et al., 2012). Diferentes autores consideram a citocinese parte da telófase, o que continua sendo uma das principais questões não resolvidas em biologia celular básica; contudo, modificações características dessa fase podem ser bem evidenciadas, como a constrição do citoplasma e a formação do anel contrátil, como evidenciado e relatado por Eggert e colaboradores (EGGERT et al., 2006). Em células animais, essa divisão é do tipo centrípeta, pois a clivagem do citoplasma em duas seções parte das extremidades em direção ao centro da célula (TANAKA et al., 2015).

\section{AGENTES DELETÉRIOS}

Diferentes tipos de radiações e vários compostos químicos podem acarretar danos ao DNA. Radiações que possuem comprimentos de onda inferiores a 400nm podem causar dano indiretamente ou diretamente ao ácido nucleico. Estas 
ondas podem ser agrupadas em ondas ionizantes e não ionizantes, dependendo do grau de energia (BECK et al., 2013).

Os raios $X$ e os raios gama são exemplos de radiações ionizantes capazes de penetrar facilmente nos tecidos celulares. Ao atravessar a matéria orgânica, essas radiações colidem com átomos, liberam os elétrons das moléculas e dão origem a radicais livres e íons reativos. Esses compostos apresentam a capacidade de ocasionar alterações estruturais em outros componentes celulares, em particular no código genético (ALIZADEH \& SANCHE, 2013). Os principais efeitos das radiações ionizantes no DNA são danos nos anéis de purinas e pirimidinas, perda de bases nitrogenadas ou quebra de uma ou ambas as fitas de DNA (KAUR et al., 2015).

As radiações não ionizantes não apresentam energia suficiente para promover a liberação de elétrons e seu poder de penetração celular é reduzido em seres pluricelulares. No entanto, apresentam poder deletério à molécula de DNA e principalmente por atuarem na radiólise da água, o que gera os radicais hidroxila extremamente reativos (OH) (VALBERG, 1997; KAUR et al., 2015).

Os raios ultravioletas (UV) são capazes de afetar indiretamente o DNA, ocasionando quebras na estrutura molecular ou provocando alterações de bases nitrogenadas. Os fotoprodutos mais comuns da excitação de pirimidinas, que são originados pela radiação UV, são os hidratos de pirimidinas e os dímeros formados de pirimidinas adjacentes. Dentre essas possíveis alterações, os dímeros formados entre adeninas adjacentes apresentam maior implicação mutagênica, impedindo o emparelhamento das bases nitrogenadas subsequentes, perturbando assim a estrutura das duplas hélices, o que interfere na precisão da duplicação do DNA (VALBERG, 1997; PRICE et al., 2014).

\section{ALTERAÇÕES QUE OCORREM NO DNA}

O genoma celular está sujeito a várias alterações espontâneas que ocorrem comumente durante a replicação celular. Os erros mais corriqueiros consistem na formação de nucleotídeos na forma tautomérica não usual na fita de DNA sintetizada, ou mesmo a presença desses nucleotídeos na fita molde no momento em que a fita dupla está sendo emparelhada com um novo nucleotídeo (PENG et al., 2015).

A tautomérica é um caso particular de isomeria funcional característico das bases nitrogenadas. A citosina e a adenina apresentam duas formas estruturais possíveis: um arranjo molecular amino, estrutura molecular mais resistente, comumente encontrado na fita de DNA, e outro arranjo molecular menos corriqueiro, imino, que proporciona uma estrutura conformacional instável. Este é passível de produzir pontes de hidrogênio com outras bases nitrogenadas diferente das contrapartes guanina e timina, respectivamente. A guanina e timina também apresentam formas tautoméricas, sendo a estrutura mais usual a conformação ceto e a forma menos usual a conformação enol (CERÓN-CARRASCO et al., 2009; LUBES et al., 2014).

A conformação amino e ceto são as formas tautoméricas mais estáveis das bases nitrogenadas e dão origem ao emparelhamento convencional das bases nitrogenadas comumente encontradas, adenina, guanina, citosina e timina, comportamento que não é observado nas formas tautomérica enol e imino. A citosina imino se emparelha por meio de pontes de hidrogênio com a adenina na forma tautomérica amino; porém, quando a conformação imino da citosina retorna à sua conformação amino normal, as ligações por pontes de hidrogênio se desfazem, 
promovendo um erro no sequenciamento. Este emparelhamento indevido pode ser corrigido pela própria DNA polimerase ao reconhecer a ligação equivocada (BANAVALI, 2013; ARAÚJO \& GONSALVES, 2015).

As mutações geradas por erros causados pelos envolvimentos de bases tautoméricas não usuais no momento da replicação do DNA são corrigidas por substituições entre as purinas e pirimidinas. Tais substituições também podem ser chamadas de transversões, enquanto as substituições entre purinas ou entre pirimidinas são chamadas de transições (LIU et al., 2012) (Figura 1).

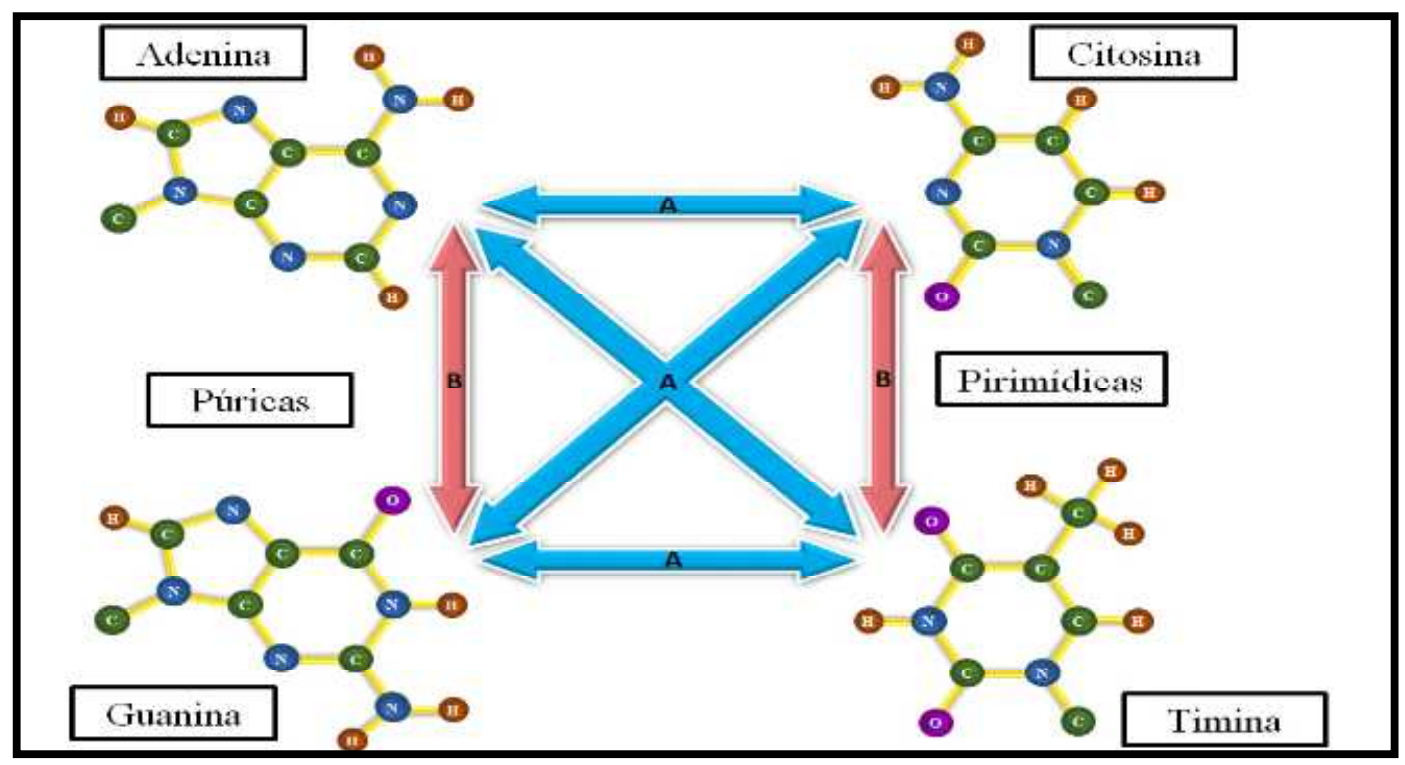

FIGURA 1 - Desenho esquemático representativo do processo de remoção de nucleotídeos entre purinas e pirimidinas passiveis de ocorrer no processo de remodelação genica. A) Formação de transversões; B) Formação de transições.

Fonte: Autoria própria.

Outras alterações espontâneas que ocorrem no DNA não dependem necessariamente do evento de replicação celular. As mesmas podem ocorrer a qualquer momento do ciclo, sendo evidenciadas as desaminações, oxidações e perda de bases. Para responder a essas ameaças, os seres vivos desenvolveram processos eficientes em resposta ao dano no DNA, com o intuito de detectar e reparar essas falhas (RHEE et al., 2013).

\section{MAQUINÁRIO DE REPARO CELULAR}

Logo após o reconhecimento do sitio danificado, proteínas que desencadeiam a interrupção do ciclo celular são acionadas, enquanto enzimas envolvidas diretamente com a correção do dano são recrutadas. Embora não existam sistemas típicos de reparo do DNA, algumas DNA polimerases que compõem o maquinário de replicação do DNA exibem atividade de revisão e correção da fita promotora (KIREEVA et al., 2013). 
Algumas enzimas apresentam capacidade de reconhecer bases nitrogenadas alteradas, corrigí-las e restabelecer as condições originais, ao promover a correção direta das bases alteradas sem envolver outros segmentos do DNA. Esse mecanismo é conhecido por reparo direto e ocorre de duas formas: reparo por excisão de base, conforme representado na Figura 2, ou reparo por excisão de nucleotídeos, esquematizado na Figura 3 (SCOTT et al., 2014).

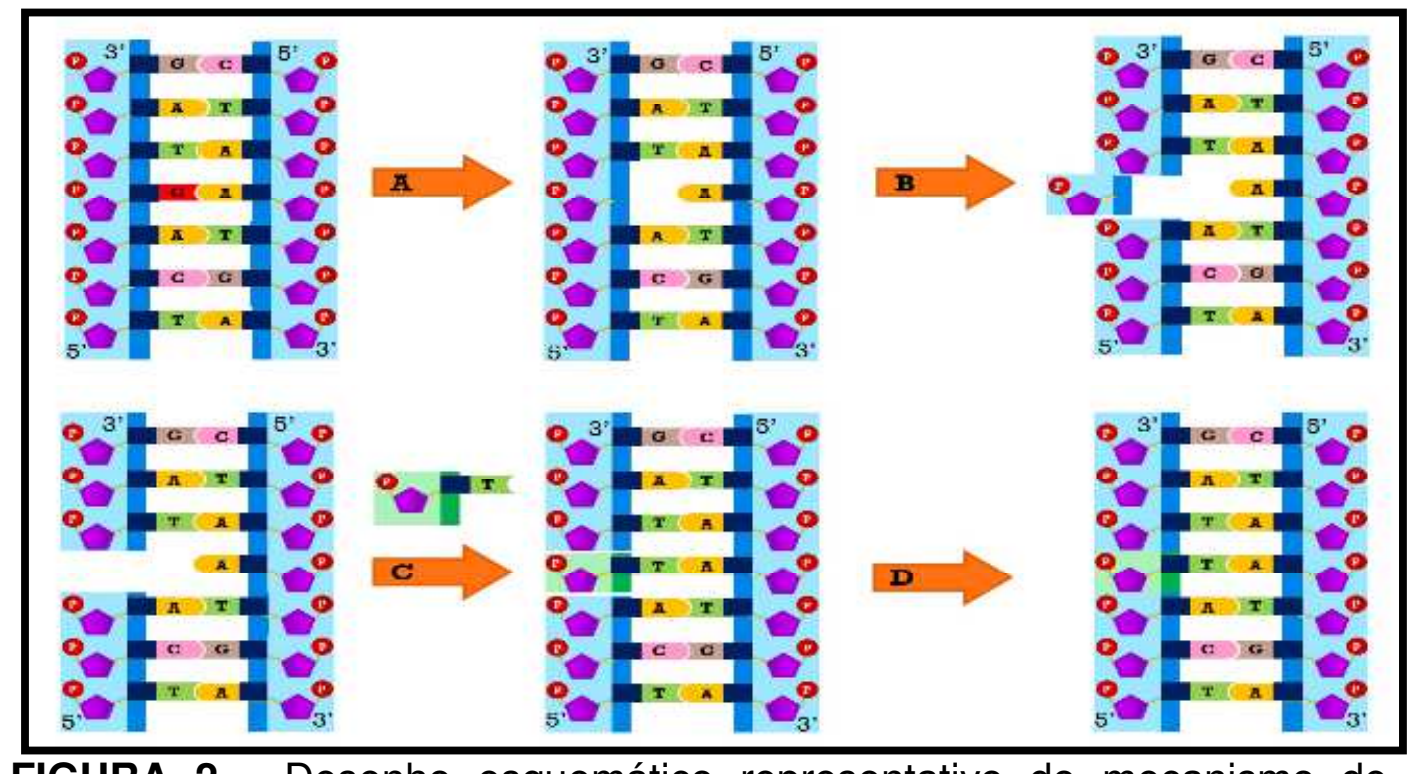

FIGURA 2 - Desenho esquemático representativo do mecanismo de excisão de base nitrogenada na fita simples de DNA, sem comprometimento de bases subsequentes. A) Remoção da base defeituosa pela DNA glicosilase; B) Remoção da pentose e fosfato pela AP-endonuclease e AP-liase; C) Preenchimento da lacuna pela DNA polimerase; D) Ligação fosfodiéster pela DNA ligase.

Fonte: Autoria própria.

O reparo por excisão de base é desencadeado pela glicosilase, que promove a remoção da base alterada. Após a incisão da base, um complexo enzimático atua nesse sitio, removendo a pentose e o fosfato que restavam do nucleotídeo. Em seguida, a DNA polimerase preenche o espaço deixado, utilizando como molde a fita complementar não danificada. Para finalizar o processo, uma DNA ligase promove a ligação fosfodiéster entre o carbono três do nucleotídeo ao carbono cinco da pentose adjacente (SCOTT et al., 2014).

O reparo por excisão de nucleotídeos é promovido por enzimas que reconhecem danos, tais como o dímero de pirimidinas. Após o reconhecimento da estrutura alterada, um complexo enzimático produz cortes no sitio danificado, o que resulta na remoção de um segmento unifilamentar. O espaço gerado, assim como no reparo por excisão de base, é preenchido pela DNA polimerase com nucleotídeos de modo consenso à fita molde, finalizando a síntese com a ligação fosfodiéster pela DNA ligase (WOOD, 1997). 


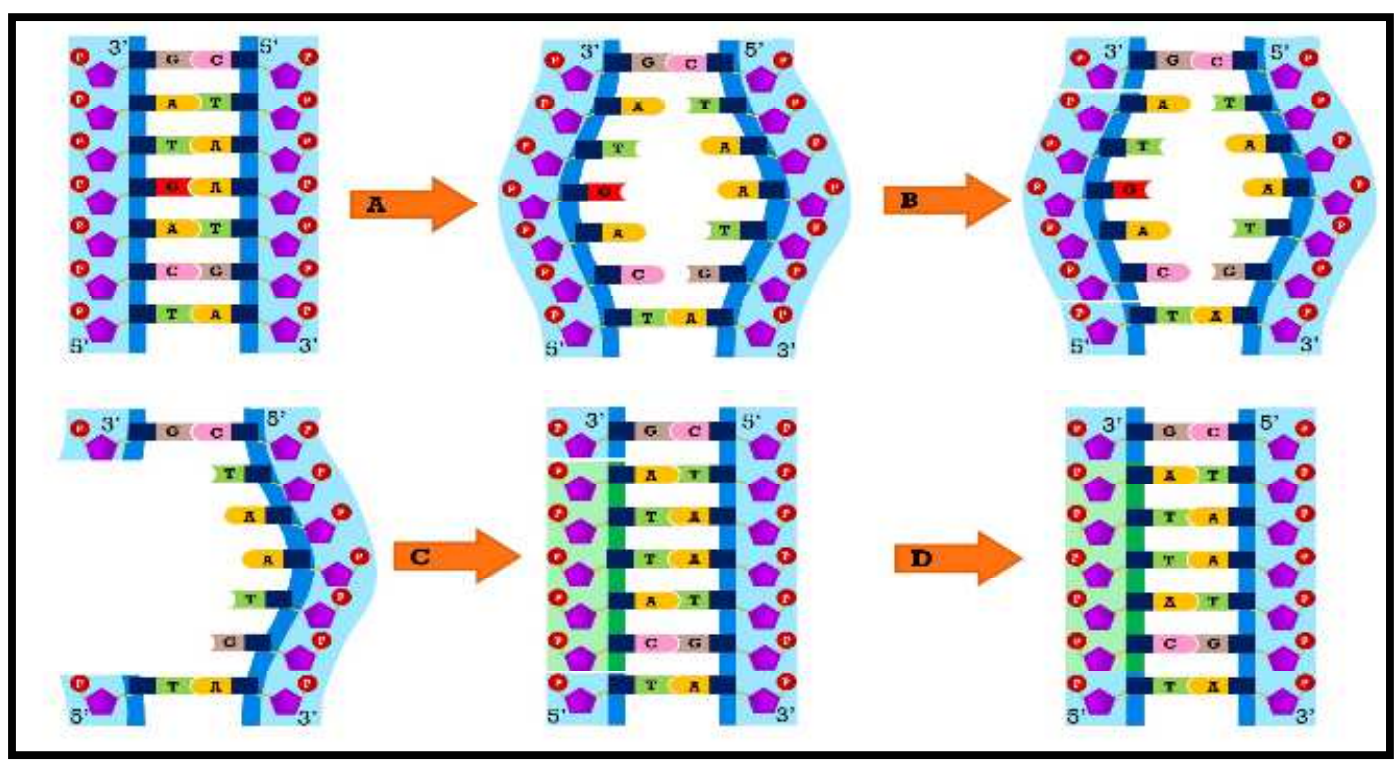

FIGURA 3 - Desenho esquemático representativo do mecanismo de excisão de nucleotídeo na fita simples de DNA, com comprometimento de bases subsequentes. A) Região maior em torno do dano é aberta num processo dependente de ATP pela TFIIH; B) O DNA é clivado no lado 3 'da lesão por XPG nuclease e no 5'-lado por ERCC1-XPF nuclease, liberando o oligonucleótido; C) Preenchimento da lacuna pela DNA polimerase; D) Ligação fosfodiéster pela DNA ligase.

Fonte: Autoria própria.

As soluções de continuidade em ambas as fitas da dupla hélice de DNA promovidas por radiações ionizantes, apesar de constituírem dano importante, ainda são passíveis de correção. Tais avarias podem ser corrigidas por meio de um mecanismo que envolve a recombinação do segmento danificado, com o segmento homólogo localizado na cromátide irmã íntegra. Por envolver na maioria das vezes cromátides-irmãs, o reparo por recombinação homóloga ocorre principalmente no final da fase $\mathrm{S}$ e em $\mathrm{G}_{2}$ (JAYAKUMAR et al., 2015).

A reparação das quebras nas fitas duplas se inicia quando proteínas específicas associam-se aos filamentos simples de DNA, invadem a molécula homóloga e restabelecem com as mesmas regiões heteroduplas. Formam-se, assim, junções conhecidas como Holliday junctions - estruturas em forma de cruz que se formam durante o processo de recombinação genética. A extremidade 3' do filamento anelar é estendida pela ação da DNA polimerase, por meio da utilização de uma das fitas da molécula homóloga como molde. Quando encerrada a síntese o filamento estendido é seccionado de forma intencional pela enzimas RuvC, o que promove o retorno da molécula invadida ao emparelhamento normal (figura 4) (CARR \& LAMBERT, 2013). 


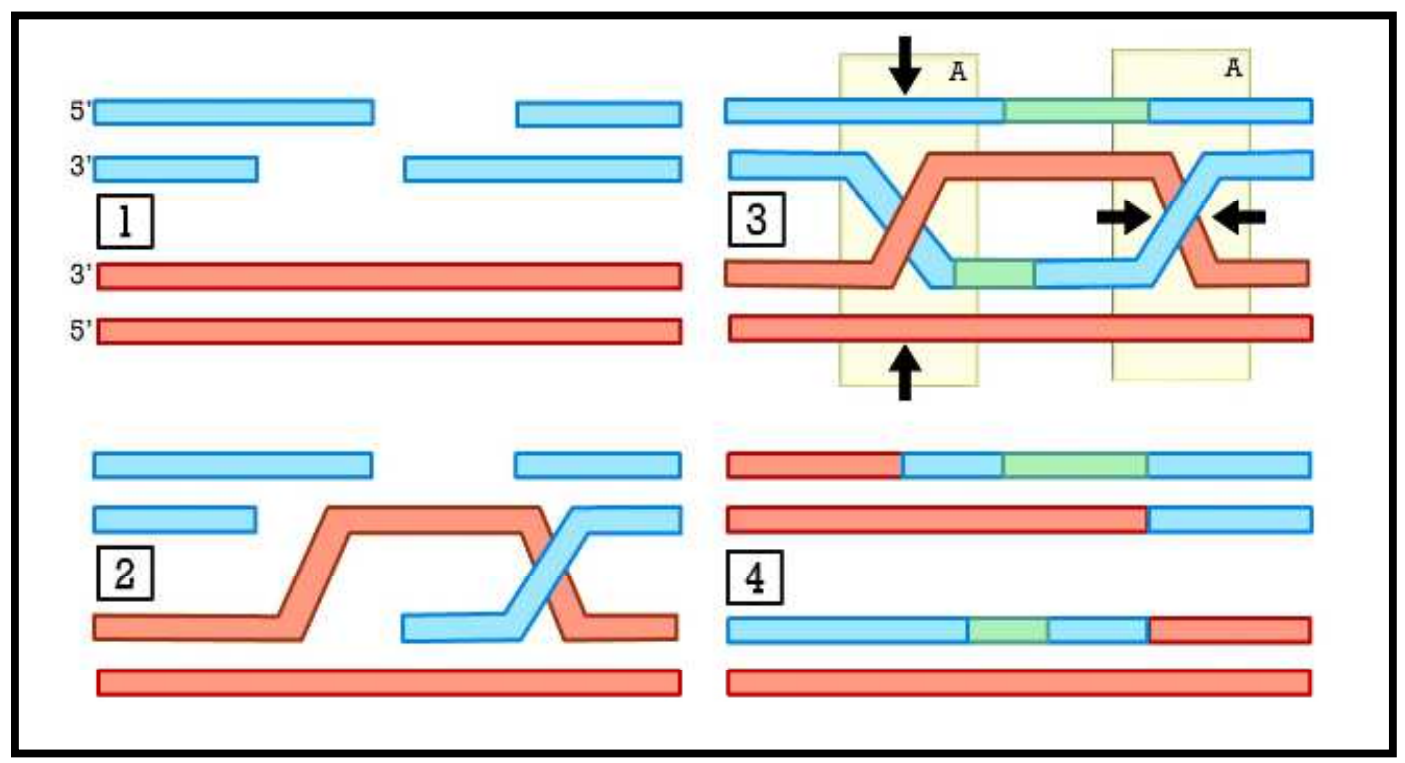

FIGURA 4 - Mecanismo de reparação do DNA com quebra de dupla ligação pelo processo de recombinação homóloga. 1) Reconhecimento da lesão pela ATM e ADNPK; 2) Migração da fita homologa pelo auxílio da proteína RecA; 3) Formação das Holliday junction demostrado pelo região em $A$ e clivagem do DNA pelas enzimas RuvC demostrado pelas setas; 4) Término da recombinação.

Fonte; Autoria própria.

Há situações em que o dano no DNA é extremo e não se dispõe de uma cromátide homologa para o reparo. Nesses casos, o mecanismo de reparo pode ser processado de duas formas: pode ocorrer a síntese aleatória de um novo segmento, que apresenta uma baixa acurácia em comparação a sequência original; e também é possível suceder a mera união das extremidades ligantes, com descarte da sequência perdida (ILIAKIS et al., 2015).

Dentre os processos citados, o reparo por união de extremidades nãohomólogas é mais recorrente, o mesmo é iniciado pelo reconhecimento da proteína ATM (ataxia telangiectasia mutated). Esta proteína apresenta grande atividade no processo de reparo celular e recruta um complexo de proteínas que auxilia a estabilização do DNA, que serve como marcador para o reconhecimento da Ku70/80. O heterodímero Ku70/80 desempenha um papel fundamental no processo de reparo, pois une as duas extremidades da fita de DNA por meio do auxílio da DNA-PK; posteriormente a DNA ligase promove a ligação fosfodiéster e finaliza o processo (figura 5) (BEGGS et al., 2012). 


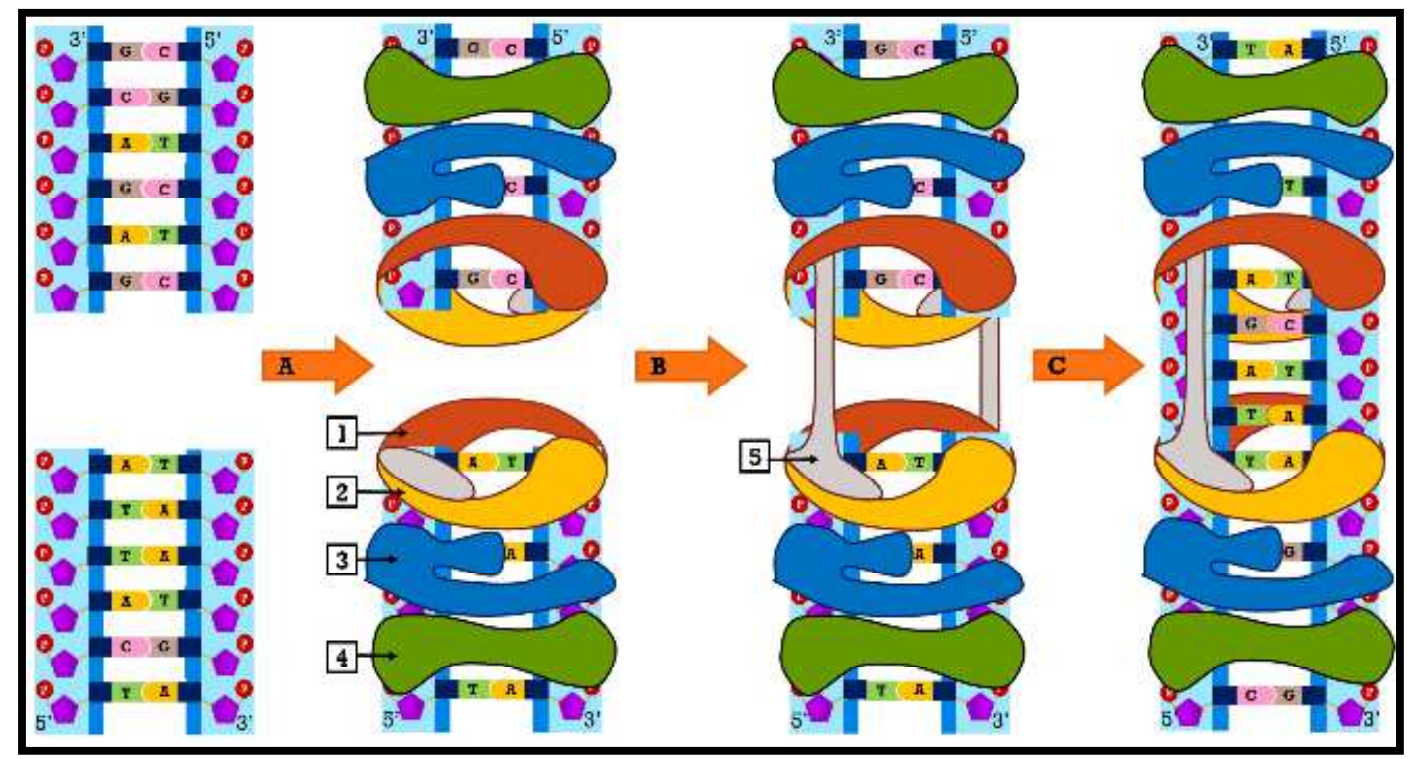

FIGURA 5 - Mecanismo de reparação do DNA com quebra de dupla ligação pelo processo de reparo por união de extremidades não-homólogas. 1) Proteína Ku70; 2) Proteína Ku80; 3) Proteína ATM; 4) Proteína yH2AX; 5) DNA-PK; A) Reconhecimento e fixação das proteínas executoras do processo de reparo por união de extremidades não-homólogas; B) emparelhamento das extremidades lesadas pela DNA-PK; C) Junção das extremidades lesadas e promoção da ligação fosfodiéster pela DNA ligase.

Fonte: Autoria própria.

\section{MECANISMO DE CONTROLE DO CICLO CELULAR}

Os pontos de verificação constituem os mecanismos pelos quais as células mantêm a vigilância e exercem a função de coordenação e sinalização do reparo do DNA. Esse sistema é gerenciado por metabólitos e proteínas que modulam as transições do ciclo celular e influenciam a estabilidade ou as atividades de outras proteínas (DIBITETTO et al., 2016).

Os componentes centrais da maquinaria dos pontos de verificação são os fosfoinositídeo-3-quinase $e$ as quinases relacionadas, ATM, ATR (ataxiatelangiectasia mutated and rad3 related) e DNAPK (DNA-dependent protein kinase catalytic sub-unit). A ATM e ADNPK reagem principalmente aos danos provenientes de ruptura de fita dupla, em quanto que a ATR é ativada em resposta a uma série de danos ao DNA durante a reparação direta, seja por reparo de excisão de base, seja por reparo de excisão de nucleotídeos. Além disso, atua também na reparação da fita dupla (ABDEL-FATAH et al., 2014).

Os danos presentes no DNA, depois de reconhecidos por essas proteínas, podem desencadear a ativação de uma cascata de sinalização que resulta na fosforilação da proteína p53. Uma vez fosforilada, essa proteína ativa a transcrição do gene codificador da proteína p21, que é responsável pela inibição da ação de quinases dependentes de ciclinas (CDKs), o que induz a parada da célula em $\mathrm{G}_{1}$ até o completo reparo do DNA. Simultaneamente, a p53 ativa o gene atuante 
no reparo do DNA. Se o processo de reparo falhar ou o dano cromossômico for muito extenso, a proteína p53 fosforilada se acumula no núcleo onde, após aumento da concentração, induz a transativação de genes que levam a célula à apoptose (ESRIG et al., 1993; SENGUPTA \& HARRIS, 2005; BERNARD et al., 2014; ARORA et al., 2015).

\section{REPARO DURANTE A FASE $\mathrm{G}_{1}$}

Os danos no DNA que afetam as células na fase de $\mathrm{G}_{1}$ são usualmente promovidos por fatores exógenos e endógenos, tais como espécies reativas de oxigênio, agentes químicos ou mesmo por radiações ionizantes. E mister que devam ser reparados antes do início da replicação (ALIZADEH \& SANCHE, 2013). A oxidação de guanina gera a formação de oxoG, composto extremamente mutagênico devido à sua possível associação com a adenina. No caso disso ocorrer, durante a replicação a fita homóloga apresentará uma transversão para timina, sendo essa uma das mutações mais comuns em diferentes tipos de câncer em humanos. Essa distorção pode ser removida pela DNA glicosilase, por meio de excisão de nucleotídeo (NER) (SCOTT et al., 2014; LI et al., 2016).

O reparo por excisão de nucleotídeo (NER) apresenta papel importante durante a fase $\mathrm{G}_{1}$, embora a atividade não esteja restrita somente a essa fase do ciclo celular. A NER é considerada a forma de reparo mais versátil. Apresenta duas vias de reconhecimento de danos do DNA: a primeira, denominada excisão de nucleotídeo do genoma global (GG-NER), opera em todo o genoma; a segunda, designada excisão de nucleotídeo acoplado a transcrição (TC-NER), remove lesões apenas de cadeias de DNA que foram transcritas. A principal diferença entre essas duas subvias encontra-se na etapa de reconhecimento de danos no DNA, pois GGNER apresenta atividade de reparo independentemente da localização do genoma e da fase do ciclo celular (MARTEIJN et al., 2014; ALEKSEEV \& COIN, 2015).

A principal implicação que advém das oxidações de bases nitrogenadas, além da capacidade mutagênica e deletéria do DNA, está relacionada com a facilidade da ocorrência desses processos. Eventualmente, quando a quantidade de danos supera a capacidade de reparo das células, esses mecanismos celulares essenciais podem ser seriamente afetados e ignorados, não ocorrem os processos normais de reparo celular e a célula é induzida a adotar outras condutas para evitar a continuidade da mutação, como senescência ou apoptose (BARREIROS et al., 2006).

Durante a fase $\mathrm{G}_{1}$, o DNA está mais propenso a lesões por radiações ionizantes, que podem provocar ruptura de fita dupla. Esse tipo de avaria ao DNA é considerável e de difícil reparação, devido à fase do ciclo em que se encontra. $O$ processo de reparação para correção desses danos consiste na união de extremidades não-homólogas (NHEJ) (JIANG et al., 2013).

Em NHEJ, o heterodímero Ku70/80 se liga às duas extremidades das fitas danificadas e recruta as subunidades catalíticas de DNA-PK e Ligase4-XRCC4 para unir as extremidades livres e unir as fitas. Tal ligação ocorre por meio das extremidades lesadas. Em situações de múltiplas rupturas de fita dupla, esse processo perde a eficácia, podendo unir segmentos errôneos, o que pode ter como consequência perda de informação genética ou translocação gênica (JIANG et al., 2013; WANG \& LEES-MILLER, 2013). 


\section{REPARO DURANTE A FASE $S$}

A síntese de DNA está frequentemente sujeita à incorporação errônea de nucleotídeos, originando lacunas (gaps) ou intervalos (nicks), ou ainda colapso na forquilha de replicação. As forquilhas de replicação degeneradas podem colocar em risco a estabilidade do DNA, se as mesmas não forem reparadas. A força de torção que é exercida quando a forquilha de replicação avança pode resultar tanto em ruptura da fita de DNA quanto no encontro de duas bolhas de replicação, o que origina a super helicoidização da fita (CHEN et al., 2013; MCKINNON, 2016).

A resolução mediada por topoisomerases dessas limitações topológicas permite a correção desses problemas de torções durante a fase $S$ por meio de uma ruptura transitória do DNA, o que reduz essas tensões sobre a fita. A operação é auxiliada pela DNA girase, que promove abertura e rotação da dupla hélice. Por sua importância nesse tipo de processo de reparação, a topoisomerase se torna uma excelente proteína alvo para fármacos anticancerígenos (CHEN et al., 2013).

Inibidores de topoisomerases agem principalmente na fase $S$, como por exemplo o irinotecan. A eficácia como agente quimioterápico com base na inibição específica da topoisomerase I é um mecanismo biológico importante no controle de células cancerígenas. Com a inativação da enzima, ocorre ruptura da fita de DNA ao longo da sequência gênica, efeito que se busca atingir na célula-alvo (BRANDÃO et al., 2010).

O desemparelhamento de bases nitrogenadas e pequenas inversões geradas por replicações defeituosas são corrigidos pelas vias de reparo direto (RD) ou pelo reparo de mau emparelhamento (RME), que funciona principalmente durante a fase S (WISEMAN \& HALLIWELL, 1996; SCHMIDT \& JACKSON, 2013). Os componentes dessas vias reconhecem e eliminam a estrutura defeituosa de DNA, removendo uma sequência de oligonucleotídeo. O espaço gerado é preenchido pela DNA polimerase e uma nova sequência de oligonucleotídeo é sintetizada. Alterações de bases de nucleotídeos são muitas vezes removidas por NER, como na fase $\mathrm{G}_{1}$ (SCOTT et al., 2014).

As lacunas ou intervalos de cadeia simples ocorrem com frequência durante a replicação, sendo a principal forma de correção promovida por reparo por recombinação homologa $(\mathrm{RH})$ em uma célula. Entretanto, essas lesões podem ser tratadas pelo mecanismo de tolerância ao dano que operam na fase $S$. As células desenvolveram dois mecanismos que promovem a tolerância aos danos em fase $S$ (IZHAR et al., 2013).

O primeiro é o mecanismo mediado pela síntese trans lesão (TLS) executado pela polimerase $\mathrm{V}$, que replica DNA por meio de lesões, estratégia muitas vezes propensa a erros. A segunda consiste na troca de moldes, executada pela polimerase II, caracterizada por ser livre de erros de replicação ao preencher as lacunas danificadas a partir das informações da fita-irmã não danificada; esse processo se assemelha com o processo de RH (IZHAR et al., 2013; MAILAND et al., 2013).

Danos de fitas duplas são passíveis de ocorrer na fase S. Por essa razão o reparo por RH ou NHEJ é executado de forma dependente das proteínas Exonuclease 1 (Exo1) e MRN. As mesmas apresentam um complexo de ligação ao DNA que durante a ruptura de fita dupla, promove a invasão da fita danificada e auxilia na formação das Holliday junctions (ZHENG et al., 2015).

Na presença de ruptura de fita dupla, os heterodímeros Ku são recrutados com uma cinética superior aos dos fatores de $\mathrm{RH}$. Portanto, é possível que possa existir competição entre NHEJ e RH, o que sugere que fatores adicionais possam 
suprimir a ligação de $\mathrm{Ku}$ e favorecerem as proteínas de $\mathrm{RH}$. Estudos recentes em células DT40 de galinha indicaram que tanto Rad18 quanto Rnf8 facilitam RH em detrimento de NHEJ ao suprimir as proteínas Ku (KOBAYASHI et al., 2015).

\section{REPARO DURANTE A FASE $\mathrm{G}_{2} \mathrm{E} M$}

As quebras de dupla ligação que ocorrem durante a replicação devem ser reparadas antes do término da fase $G_{2}$. $A R H$ pode ocorrer durante as fases $S$ e $G_{2}$; por utilizar as cromátides irmãs como modelo de replicação, é importante que as cromátides estejam na proximidade uma da outra. Esse efeito é estabelecido pela coesão fornecida por uma ligação física exercida pelas cromátides, que é rompida durante a anáfase, subfase da mitose (ABHILASH \& SINGH, 2009).

A coesão depende em grande parte pela cohesin, um complexo de proteínas formado por SMC1 e SMC3 (structural maintenance of chromosomes), em conjunto com SCC1 e SCC3 (sister-chromatid cohesion), responsáveis por manter esta estrutura. A coesão deve ser estabelecida durante a fase S e perdurar ao longo do processo de replicação. Danos no DNA por rupturas de dupla ligação durante a fase $\mathrm{G}_{2}$ se tornam extremamente complexos, em virtude da compactação do DNA e da difícil pesquisa de homologia durante o processo. Entretanto, o reparo de lesões em $\mathrm{G}_{2}$ e M é predominantemente por NHEJ (WU \& YU, 2012; ZHANG et al., 2013).

Durante a fase mitótica, há formação dos fusos mitóticos, originados a partir dos microtúbulos. Estes são essenciais para o desenvolvimento e a forma das células, transportes de componentes, sinalização celular e no processo de mitose. Alguns compostos específicos com atividade antineoplásica exercem seus efeitos interagindo com proteínas e microtúbulos, pois qualquer distúrbio nesse equilíbrio pode causar a interrupção da mitose e consequente morte da célula. Entre os anticancerígenos que atuam por tal mecanismo, podem ser citados os alcaloides da Vinca, os taxanos e a colchicina (BRANDÃO et al., 2010).

\section{REPARO DURANTE A FASE $\mathrm{G}_{0}$}

A maior frequência de danos no DNA está associada à replicação celular em células que estão em divisão. Entretanto, células que não estão em divisão celular também estão propensas a erros. Tem sido proposto que o acúmulo de danos no DNA de neurônios em humanos tem um papel crucial no envelhecimento e na patogênese de muitas doenças neurológicas, com destaque para a Doença de Alzheimer, Mal de Parkinson e ALS (amyotrophic lateral sclerosis). Os tipos de danos no DNA predominantes em neurônios são as lesões oriundas da oxidação do próprio DNA, que surgem durante o metabolismo celular normal (MIGLIORE et al., 2005; FISHEL et al., 2007).

Danos oxidativos de bases são removidos principalmente por reparação por excisão de base (BER), enquanto os adutos de DNA são reparados principalmente por NER. Este mecanismo também é importante para a sobrevivência e função adequada das células neuronais, sendo essencial para o reparo de lesões endógenas, seguido por reparação GG-NER. São poucos os relatos da reparação exercida por TLS ou NHEJ em ruptura de fita duplas. Esses processos são evitados em células terminalmente diferenciadas em virtude da importância funcional dessas células e dos processos passíveis de perda de informação gênica durante 0 processo, que inviabilizam processos metabólicos básicos de sobrevivência (SWAIN \& RAO, 2012). 


\section{CONSIDERAÇÕES FINAIS}

A reparação precisa dos danos exercidos ao DNA é de suma importância para a integridade do genoma. Caso essas lesões não sejam reparadas, essas mutações podem provocar efeitos genotóxicos severos e induzir a morte celular, ou mesmo resultar na incorporação de alterações no genoma e ser transmitidas para as gerações futuras. Além disso, podem gerar instabilidade genômica e induzir 0 aparecimento de câncer.

A regulação da reparação do DNA é dependente de dois fatores primordiais: o tipo de lesão ao DNA que necessita de reparo e as características dos substratos relacionados com o ciclo celular. Estas características incluem a expressão ou a estabilidade de certas proteínas de reparação, o grau de compactação da cromatina e a disponibilidade dos cromossomos homólogos.

As pesquisas atuais sugerem interação complexa e diafonia entre os diferentes mecanismos de regulação com sobreposição e interação entre diferentes rotas, que competem ou colaboram para reparar um mesmo processo de injúria. No entanto, muitas questões importantes sobre os detalhes moleculares e como diferentes modificações pós traducionais dos fatores de reparação podem influenciar as interações proteicas, a distribuição celular, o volume de atividade e, por fim, a reparação eficiente do DNA, ainda não são esclarecidas.

Em estudos subsequentes, espera-se alcançar melhor compreensão dos mecanismos que controlam os processos de reparação do DNA e coordenar o reparo com a progressão do ciclo celular. Novas descobertas poderão esclarecer as etapas que envolvem a preservação da integridade genômica ou canalizar esses conhecimentos para descobertas de fármacos que atuem diretamente no DNA em etapas cruciais da replicação celular, com a finalidade de promover a morte de células tumorais.

\section{REFERÊNCIAS}

ABdel-FatAh, T. M., ARORA, A., MOSELEY, P., COVENEY, C., PERRY, C., JOHNSON, $K$. et al. ATM, ATR and DNA-PKcs expressions correlate to adverse clinical outcomes in epithelial ovarian cancers. BBA clinical, v. 2, p. 10-17, 2014. Disponível em: < http://dx.doi.org/10.1016/j.bbacli.2014.08.001 >. doi: 10.1016/j.bbacli.2014.08.001.

ABHILASH, P.; SINGH, N. Pesticide use and application: an Indian scenario. Journal of hazardous materials, v. 165 , n. 1, p. 1-12, 2009. Disponível em: < http://www.sciencedirect.com/science/article/pii/S0304389408015409 >. doi: 10.1016/j.jhazmat.2008.10.061.

ALEKSEEV, S.; COIN, F. Orchestral maneuvers at the damaged sites in nucleotide excision repair. Cellular and Molecular Life Sciences, v. 72 , n. 11, p. 2177-2186, 2015. Disponível em: < https://link.springer.com/article/10.1007/s00018-015-1859-5 >. doi: $10.1007 / \mathrm{s} 00018-015-1859-5$.

ALIZADEH, E.; SANCHE, L. Role of humidity and oxygen level on damage to DNA induced by soft X-rays and low-energy electrons. The Journal of Physical Chemistry C, v. 117, n. 43 , p. 22445-22453, 2013. Disponível em: < https://www.ncbi.nlm.nih.gov/pmc/articles/PMC4072655/ >. doi: 10.1021/jp403350j. 
ARAÚJO, C. R. M.; GONSALVES, A. A. Oximas: Propriedades Químicas, Métodos de Preparação e Aplicações na Síntese de Grupos Funcionais Nitrogenados. Revista Virtual de Química, v. 7, n. 4, p. 1469-1495, 2015. Disponível em: < http://rvq.sbq.org.br/default.asp?ed=15 >. doi: 10.5935/1984-6835.20150080.

ARORA, S., TYAGI, N., BHARDWAJ, A., RUSU, L., PALANKI, R., VIG, K. et al. Silver nanoparticles protect human keratinocytes against UVB radiation-induced DNA damage and apoptosis: potential for prevention of skin carcinogenesis. Nanomedicine: Nanotechnology, Biology and Medicine, v. 11, n. 5, p. 1265-1275, 2015. Disponível em:

$<$ http://www.sciencedirect.com/science/article/pii/S1549963415000775 >. doi: 10.1016/j.nano.2015.02.024.

BANAVALI, N. K. Partial base flipping is sufficient for strand slippage near DNA duplex termini. Journal of the American Chemical Society, v. 135, n. 22, p. 82748282, 2013. Disponível em: < http://pubs.acs.org/doi/abs/10.1021/ja401573j >. doi: 10.1021/ja401573j.

BARREIRO-ALONSO, A., LAMAS-MACEIRAS, M., RODRÍGUEZ-BELMONTE, E., VIZOSO-VÁZQUEZ, Á., QUINDÓS, M., CERDÁN, M. E. High mobility group B proteins, their partners, and other redox sensors in ovarian and prostate cancer. Oxidative medicine and cellular longevity, v. 2016, 2015. Disponível em: < https://www.ncbi.nlm.nih.gov/pubmed/26682011 >. doi: 10.1155/2016/5845061.

BARREIROS, A. L.; DAVID, J. M.; DAVID, J. P. Oxidative stress: relations between the formation of reactive species and the organism's defense. Química Nova, v. 29, n. 1, p. 113-123, 2006. Disponível em: < http://www.scielo.br/scielo.php?pid=S010040422006000100021\&amp;amp;script=sci_arttext >. doi: 10.1590/S010040422006000100021

BECK, S. E., RODRIGUEZ, R. A., LINDEN, K. G., HARGY, T. M., LARASON, T. C., WRIGHT, H. B. Wavelength dependent UV inactivation and DNA damage of adenovirus as measured by cell culture infectivity and long range quantitative PCR. Environmental science \&amp; technology, v. 48, n. 1, p. 591-598, 2013. Disponível em: < http://pubs.acs.org/doi/abs/10.1021/es403850b >. doi: 10.1021/es403850b.

BEGGS, A. D., DOMINGO, E., MCGREGOR, M., PRESZ, M., JOHNSTONE, E., MIDGLEY, R. et al. Loss of expression of the double strand break repair protein ATM is associated with worse prognosis in colorectal cancer and loss of Ku70 expression is associated with CIN. Oncotarget, v. 3, n. 11, p. 1348-1355, 2012. Disponível em: < http://europepmc.org/articles/PMC3717797 >. doi: 10.18632/oncotarget.694.

BERNARD, J. J., LOU, Y. R., PENG, Q. Y., LI, T., CONNEY, A. H., LU, Y. P. Inverse relationship between p53 and phospho-Chk1 (Ser317) protein expression in UVBinduced skin tumors in SKH-1 mice. Experimental and molecular pathology, v. 96, n. 1 , p. 126-131, 2014. Disponível em: < http://dx.doi.org/10.1016/j.yexmp.2013.10.011 >. doi: 10.1016/j.yexmp.2013.10.011. 
BERTOLI, C.; SKOTHEIM, J. M.; DE BRUIN, R. A. Control of cell cycle transcription during $\mathrm{G} 1$ and $S$ phases. Nature reviews Molecular cell biology, v. 14, n. 8, p. 518528 , 2013.

Disponível em:

http://www.nature.com/nrm/journal/v14/n8/abs/nrm3629.html $>$.

doi: 10.1038/nrm3629.

BLANPAIN, C.; SIMONS, B. D. Unravelling stem cell dynamics by lineage tracing. Nature reviews Molecular cell biology, v. 14, n. 8, p. 489-502, 2013. Disponível em: < http://www.nature.com/nrm/journal/v14/n8/abs/nrm3625.html >. doi: $10.1038 / \mathrm{nrm} 3625$.

BRANDÃO, H. N.; DAVID, J. P.; COUTO, R. D.; NASCIMENTO, J. A.; DAVID, J. M. Chemistry and pharmacology of antineoplasic chemoterapeutical derivatives from plants. Química Nova, v. 33, n. 6, p. 1359-1369, 2010. Disponível em: < http://www.scielo.br/scielo.php?pid=S0100-

40422010000600026\&amp;amp;script=sci_arttext >. doi: 10.1590/S010040422010000600026

CARR, A. M.; LAMBERT, S. Replication stress-induced genome instability: the dark side of replication maintenance by homologous recombination. Journal of molecular biology, v. 425, n. 23, p. 4733-4744, 2013. Disponível em: < http://www.sciencedirect.com/science/article/pii/S0022283613002714 >. doi: 10.1016/j.jmb.2013.04.023.

CECCALDI, R.; RONDINELLI, B.; D'ANDREA, A. D. Repair pathway choices and consequences at the double-strand break. Trends in cell biology, v. 26, n. 1, p. 5264, 2016. Disponível em: < http://www.sciencedirect.com/science/article/pii/S0962892415001427 >. doi: 10.1016/j.tcb.2015.07.009.

CERÓN-CARRASCO, J. P., REQUENA, A., ZÚÑIGA, J., MICHAUX, C., PERPÈTE, E. A., JACQUEMIN, D. Intermolecular proton transfer in microhydrated guaninecytosine base pairs: A new mechanism for spontaneous mutation in DNA. The Journal of Physical Chemistry A, v. 113, n. 39, p. 10549-10556, 2009. Disponível em: < https://www.ncbi.nlm.nih.gov/pubmed/19736955 >. doi: 10.1021/jp906551f.

CHAUDHARY, P., SHARMA, R., SAHU, M., VISHWANATHA, J. K., AWASTHI, S., AWASTHI, Y. C. 4-Hydroxynonenal induces G2/M phase cell cycle arrest by activation of the ataxia telangiectasia mutated and Rad3-related protein (ATR)/checkpoint kinase 1 (Chk1) signaling pathway. Journal of Biological Chemistry, v. 288, n. 28, p. 20532-20546, 2013. Disponível em: < http://www.jbc.org/content/288/28/20532.short >. doi: 10.1152/ajpcell.00101.2016.

CHAUHAN, N.; VISRAM, M.; CRISTOBAL-SARRAMIAN, A.; SARKLETI, F.; KOHLWEIN, S. D. Morphogenesis checkpoint kinase Swe1 is the executor of lipolysis-dependent cell-cycle progression. Proceedings of the National Academy of Sciences, v. 112, n. 10, p. E1077-E1085, 2015. Disponível em: < http://www.pnas.org/content/112/10/E1077.short >. doi: 10.1073/pnas.1423175112. 
CHEN, S. H.; CHAN, N.-L.; HSIEH, T.-S. New mechanistic and functional insights into DNA topoisomerases. Annual review of biochemistry, v. 82, p. 139-170, 2013. Disponível em: < http://annualreviews.org/doi/abs/10.1146/annurev-biochem-061809100002 >. doi: 10.1146/annurev-biochem-061809-100002.

DE JESÚS RODRÍGUEZ-GÓMEZ, A.; FRÍAS-VÁZQUEZ, S. Mitosis and its regulation. Acta Pediátrica de México, v. 35, n. 1, p. 55-68, 2014. Disponível em: < http://ojs.actapediatrica.org.mx/index.php/APM/article/view/1029 >. doi: 10.18233/APM35No1pp48-61.

DIBITETTO, D., FERRARI, M., RAWAL, C. C., BALINT, A., KIM, T., ZHANG, Z. et al. Slx4 and Rtt107 control checkpoint signalling and DNA resection at double-strand breaks. Nucleic acids research, v. 44, n. 2, p. 669-682, 2016. Disponível em: < https://academic.oup.com/nar/article/44/2/669/2468124/SIx4-and-Rtt107-controlcheckpoint-signalling-and >. doi: 10.1093/nar/gkv1080.

DOMINGUEZ-BRAUER, C., THU, K. L., MASON, J. M., BLASER, H., BRAY, M. R., MAK, T. W. Targeting mitosis in cancer: emerging strategies. Molecular cell, v. 60, n. 4, p. 524-536, 2015. Disponível em: < http://www.sciencedirect.com/science/article/pii/S1097276515008667 >. doi: 10.1016/j.molcel.2015.11.006.

EGGERT, U. S.; MITCHISON, T. J.; FIELD, C. M. Animal cytokinesis: from parts list to mechanisms. Annu. Rev. Biochem., v. 75, p. 543-566, 2006. Disponível em: < http://annualreviews.org/doi/abs/10.1146/annurev.biochem.74.082803.133425 >. doi: 10.1146/annurev.biochem.74.082803.133425.

ESRIG, D. SPRUCK, 3RD, C. H. NICHOLS, P. W. CHAIWUN, B. STEVEN, K. GROSHEN, S. et al. p53 nuclear protein accumulation correlates with mutations in the p53 gene, tumor grade, and stage in bladder cancer. The American journal of pathology, v. 143, n. 5, p. 1389-1397, 1993. Disponível em: < http://www.ncbi.nlm.nih.gov/pmc/articles/PMC1887166/ >.

FISHEL, M. L.; VASKO, M. R.; KELLEY, M. R. DNA repair in neurons: so if they don't divide what's to repair? Mutation Research/Fundamental and Molecular Mechanisms of Mutagenesis, v. 614, n. 1, p. 24-36, 2007. Disponível em: < http://www.sciencedirect.com/science/article/pii/S0027510706002004 >. doi: 10.1016/j.mrfmmm.2006.06.007.

FOLLAIN, G.; MERCIER, L.; OSMANI, N.; HARLEPP, S.; GOETZ, J. G. Seeing is believing: multi-scale spatio-temporal imaging towards in vivo cell biology. J Cell Sci, p. jcs. 189001, 2016. Disponível em: < http://jcs.biologists.org/content/130/1/23 > . doi: $10.1242 /$ jcs.189001.

ILIAKIS, G.; MURMANN, T.; SONI, A. Alternative end-joining repair pathways are the ultimate backup for abrogated classical non-homologous end-joining and homologous recombination repair: Implications for the formation of chromosome translocations. Mutation Research/Genetic Toxicology and Environmental Mutagenesis, v. 793 , p. 166-175, 2015. Disponível em: < 
http://www.sciencedirect.com/science/article/pii/S1383571815001795

>. doi:

10.1016/j.mrgentox.2015.07.001.

IZHAR, L.; ZIV, O.; COHEN, I. S.; GEACINTOV, N. E.; LIVNEH, Z. Genomic assay reveals tolerance of DNA damage by both translesion DNA synthesis and homologydependent repair in mammalian cells. Proceedings of the National Academy of Sciences, v. 110, n. 16, p. E1462-E1469, 2013. Disponível em: < http://www.pnas.org/content/110/16/E1462.short >. doi: 10.1073/pnas.1216894110.

JAYAKUMAR, S.; PAL, D.; SANDUR, S. K. Nrf2 facilitates repair of radiation induced DNA damage through homologous recombination repair pathway in a ROS independent manner in cancer cells. Mutation Research/Fundamental and Molecular Mechanisms of Mutagenesis, v. 779, p. 33-45, 2015. Disponível em: < http://www.sciencedirect.com/science/article/pii/S0027510715300130 >. doi: 10.1016/j.mrfmmm.2015.06.007.

JIANG, G., PLO, I., WANG, T., RAHMAN, M., CHO, J. H., YANG, E. et al. BRCA1Ku80 protein interaction enhances end-joining fidelity of chromosomal double-strand breaks in the G1 phase of the cell cycle. Journal of Biological Chemistry, v. 288, n. 13, p. 8966-8976, 2013. Disponível em: < http://www.jbc.org/content/288/13/8966.short >. doi: 10.1074/jbc.M112.412650.

KAUR, H.; SHARMA, P.; SHEORAN, P. DNA Repair and Acclimatisation to Damage under lonizing Radiations. LS: International Journal of Life Sciences, v. 4, n. 3, p. 165-187, 2015.

Disponível

em:

http://www.indianjournals.com/ijor.aspx?target=ijor:Isijls\&amp;amp;volume=4\&amp;a mp;issue=3\&amp;amp;article=006 > . doi: 10.5958/2319-1198.2015.00023.8.

KIREEVA, M. L.; KASHLEV, M.; BURTON, Z. F. RNA polymerase structure, function, regulation, dynamics, fidelity, and roles in gene expression. Chemical reviews, v. 113, n. 11, p. 8325-8330, 2013. Disponível em: < https://www.ncbi.nlm.nih.gov/pmc/articles/PMC3900282/ >. doi: 10.1021/cr400436m.

KOBAYASHI, S., KASAISHI, Y., NAKADA, S., TAKAGI, T., ERA, S., MOTEGI, A., et al. Rad18 and Rnf8 facilitate homologous recombination by two distinct mechanisms, promoting Rad51 focus formation and suppressing the toxic effect of nonhomologous end joining. Oncogene, v. 34, n. 33, p. 4403-4411, 2015. Disponível em: < http://www.nature.com/onc/journal/v34/n33/abs/onc2014371a.html >. doi: 10.1038/onc.2014.371.

LI, P.; RAMM, G. A.; MACDONALD, G. A. Value of the 8-oxodG/dG ratio in chronic liver inflammation of patients with hepatocellular carcinoma. Redox biology, v. 8, p. 259-270, 2016. Disponível em: http://www.sciencedirect.com/science/article/pii/S2213231716300143 >. doi: 10.1016/j.redox.2016.02.003.

LING, H.; KULASIRI, D.; SAMARASINGHE, S. Robustness of G1/S checkpoint pathways in cell cycle regulation based on probability of DNA-damaged cells passing as healthy cells. Biosystems, v. 101, n. 3, p. 213-221, 2010. Disponível em: < 
LIU, Q., GUO, Y., LI, J., LONG, J., ZHANG, B., SHYR, Y. Steps to ensure accuracy in genotype and SNP calling from Illumina sequencing data. BMC genomics, v. 13, n. 8,2012 p. $1, \quad$ Disponível em: < https://bmcgenomics.biomedcentral.com/articles/10.1186/1471-2164-13-S8-S8 >. doi: 10.1186/1471-2164-13-S8-S8.

LOPEZ, B. S.; PASERO, P.; LAMBERT, S. A. The causes of replication stress and their consequences on genome stability and cell fate. Seminars in cell \&amp; developmental biology, v. 30, p. 154-164, 2014. Disponível em: < http://www.sciencedirect.com/science/article/pii/S1084952114001062 >. doi: 10.1016/j.semcdb.2014.04.035.

LUBES, G.; GÓMEZ, G.; HERNÁNDEZ, L.; DEL CARPIO, E.; LUBES, V. Theoretical Studies of (E)-2-[(2-Chloro-benzylimino)-Methyl]-Methoxyphenol, a Schiff base. Avances en Química, v. 9, n. 1, p. 29-36, 2014. Disponível em: < http://www.saber.ula.ve/handle/123456789/38505 >.

MAILAND, N.; GIBBS-SEYMOUR, I.; BEKKER-JENSEN, S. Regulation of PCNAprotein interactions for genome stability. Nature reviews Molecular cell biology, v. 14, n. 5, p. 269-282, 2013. Disponível em: < http://www.nature.com/nrm/journal/v14/n5/abs/nrm3562.html >. doi: 10.1038/nrm3562.

MAO, A. S.; SHIN, J.-W.; MOONEY, D. J. Effects of substrate stiffness and cell-cell contact on mesenchymal stem cell differentiation. Biomaterials, v. 98, p. 184-191, 2016. Disponível em: http://www.sciencedirect.com/science/article/pii/S014296121630165X >. doi: 10.1016/j.biomaterials.2016.05.004.

MARTEIJN, J. A.; LANS, H.; VERMEULEN, W.; HOEIJMAKERS, J. H. Understanding nucleotide excision repair and its roles in cancer and ageing. Nature reviews Molecular cell biology, v. 15, n. 7, p. 465-481, 2014. Disponível em: < http://www.nature.com/nrm/journal/v15/n7/abs/nrm3822.html >. doi: $10.1038 / \mathrm{nrm} 3822$.

MCKINNON, P. J. Topoisomerases and the regulation of neural function. Nature Reviews Neuroscience, 2016. Disponível em: < http://www.nature.com/nrn/journal/v17/n11/full/nrn.2016.101.html >. doi: 10.1038/nrn.2016.101.

MIGLIORE, L., FONTANA, I., COLOGNATO, R., COPPEDE, F., SICILIANO, G., MURRI, L. Searching for the role and the most suitable biomarkers of oxidative stress in Alzheimer's disease and in other neurodegenerative diseases. Neurobiology of aging, v. 26, n. 5, p. 587-595, 2005. Disponível em: < http://www.sciencedirect.com/science/article/pii/S019745800400332X >. doi: 10.1016/j.neurobiolaging.2004.10.002. 
NOUSPIKEL, T. Genetic instability in human embryonic stem cells: prospects and caveats. Future Oncology, v. 9, n. 6, p. 867-877, 2013. Disponível em: < http://www.futuremedicine.com/doi/abs/10.2217/fon.13.22?journalCode=fon >. doi: 10.2217/fon.13.22.

O'DONNELL, M.; LANGSTON, L.; STILLMAN, B. Principles and concepts of DNA replication in bacteria, archaea, and eukarya. Cold Spring Harbor perspectives in biology, v. 5, n. 7, p. a010108, 2013. Disponível em: < http://cshperspectives.cshlp.org/content/5/7/a010108.short >. doi: 10.1101/cshperspect.a010108.

PENG, C. S., FEDELES, B. I., SINGH, V., LI, D., AMARIUTA, T., ESSIGMANN, J. M., et al. Two-dimensional IR spectroscopy of the anti-HIV agent KP1212 reveals protonated and neutral tautomers that influence $\mathrm{pH}$-dependent mutagenicity. Proceedings of the National Academy of Sciences, v. 112, n. 11, p. 3229-3234, 2015. Disponível em: < http://www.pnas.org/content/112/11/3229.short >. doi: 10.1073/pnas.1415974112.

PIERRON, G. Basis for Molecular Genetics in Cancer. In: (Ed.). Pan-cancer Integrative Molecular Portrait Towards a New Paradigm in Precision Medicine: Springer, 2015. p.15-30.

PRICE, N. E., JOHNSON, K. M., WANG, J., FEKRY, M. I., WANG, Y., GATES, K. S. Interstrand DNA-DNA cross-link formation between adenine residues and abasic sites in duplex DNA. Journal of the American Chemical Society, v. 136, n. 9, p. 3483-3490, 2014. Disponível em: < http://pubs.acs.org/doi/abs/10.1021/ja410969x >. doi: $10.1021 / \mathrm{ja} 410969 x$.

REDON, C. E., NAKAMURA, A. J., MARTIN, O. A., PAREKH, P. R., WEYEMI, U. S., BONNER, W. M. Recent developments in the use of $\mathrm{y}-\mathrm{H} 2 \mathrm{AX}$ as a quantitative DNA double-strand break biomarker. Aging (Albany NY), v. 3, n. 2, p. 168-74, 2011. Disponível em: < http://www.aging-us.com/article/100284/text > doi: 10.18632/aging.100284.

RHEE, J. S., KIM, B. M., KIM, R. O., SEO, J. S., KIM, I. C., LEE, Y. M. et al. Coexpression of antioxidant enzymes with expression of p53, DNA repair, and heat shock protein genes in the gamma ray-irradiated hermaphroditic fish Kryptolebias marmoratus larvae. Aquatic toxicology, v. 140, p. 58-67, 2013. Disponível em: < http://www.sciencedirect.com/science/article/pii/S0166445X13001197 >. doi: 10.1016/j.aquatox.2013.05.006.

SAMWER, M., DEHNE, H. J., SPIRA, F., KOLLMAR, M., GERLICH, D. W., URLAUB, $\mathrm{H}$. et al. The nuclear F-actin interactome of Xenopus oocytes reveals an actin-bundling kinesin that is essential for meiotic cytokinesis. The EMBO journal, v. 32, n. 13, p. 1886-1902, 2013. Disponível em: < http://emboj.embopress.org/content/32/13/1886 > . doi: 10.1038/emboj.2013.108.

SCHMIDT, C. K.; JACKSON, S. P. On your mark, get SET (D2), go! H3K36me3 primes DNA mismatch repair. Cell, v. 153, n. 3, p. 513-515, 2013. Disponível em: < 
http://www.sciencedirect.com/science/article/pii/S0092867413004601 >. doi: 10.1016/j.cell.2013.04.018.

SCOTT, T. L.; RANGASWAMY, S.; WICKER, C. A.; IZUMI, T. Repair of oxidative DNA damage and cancer: recent progress in DNA base excision repair. Antioxidants \&amp; redox signaling, v. 20, n. 4, p. 708-726, 2014. Disponível em: $<\quad$ http://online.liebertpub.com/doi/abs/10.1089/ars.2013.5529 >. doi: 10.1089/ars.2013.5529.

SENGUPTA, S.; HARRIS, C. C. p53: traffic cop at the crossroads of DNA repair and recombination. Nature reviews Molecular cell biology, v. 6, n. 1, p. 44-55, 2005. Disponível em: < http://www.nature.com/nrm/journal/v6/n1/abs/nrm1546.html >. doi: doi:10.1038/nrm1546.

SPERKA, T.; WANG, J.; RUDOLPH, K. L. DNA damage checkpoints in stem cells, ageing and cancer. Nature reviews Molecular cell biology, v. 13, n. 9, p. 579-590, 2012. Disponível em: < http://www.nature.com/nrm/journal/v13/n9/abs/nrm3420.html >. doi: $10.1038 / \mathrm{nrm} 3420$.

SWAIN, U.; RAO, K. S. Base Excision DNA Repair: The House Keeping Guardian for Genomic Stability in the Brain. In: (Ed.). Brain Aging and Therapeutic Interventions: Springer, 2012. p.19-36. ISBN 9400752369.

SYAM, S., BUSTAMAM, A., ABDULLAH, R., SUKARI, M. A., HASHIM, N. M., GHADERIAN, M. et al. $\beta$-Mangostin induces p53-dependent G2/M cell cycle arrest and apoptosis through ROS mediated mitochondrial pathway and NfkB suppression in MCF-7 cells. Journal of Functional Foods, v. 6, p. 290-304, 2014. Disponível em: < http://www.sciencedirect.com/science/article/pii/S1756464613002466 >. doi: 10.1016/j.jff.2013.10.018.

TANAKA, A., DE MARTINO, A., AMATO, A., MONTSANT, A., MATHIEU, B., ROSTAING, P. et al. Ultrastructure and membrane traffic during cell division in the marine pennate diatom Phaeodactylum tricornutum. Protist, v. 166, n. 5, p. 506-521, $2015 . \quad$ Disponível em: < http://www.sciencedirect.com/science/article/pii/S1434461015000498 >. doi: 10.1016/j.protis.2015.07.005.

THORENOOR, N., FALTEJSKOVA-VYCHYTILOVA, P., HOMBACH, S., MLCOCHOVA, J., KRETZ, M., SVOBODA, M. et al. Long non-coding RNA ZFAS1 interacts with CDK1 and is involved in p53-dependent cell cycle control and apoptosis in colorectal cancer. Oncotarget, v. 7, n. 1, p. 622, 2016. Disponível em: $<\quad$ https://www.ncbi.nlm.nih.gov/pmc/articles/PMC4808022/ >. doi: 10.18632/oncotarget.5807.

TIANG, C.-L.; HE, Y.; PAWLOWSKI, W. P. Chromosome organization and dynamics during interphase, mitosis, and meiosis in plants. Plant physiology, v. 158, n. 1, p. 26-34, 2012. Disponível em: < http://www.plantphysiol.org/content/158/1/26.short >. doi: 10.1104/pp.111.187161. 
VALBERG, P. A. Radio frequency radiation (RFR): the nature of exposure and carcinogenic potential. Cancer Causes \&amp; Control, v. 8, n. 3, p. 323-332, 1997. Disponível em: < https://link.springer.com/article/10.1023/A:1018449003394 >. doi: 10.1023/A:1018449003394.

VICENTE, J.-J.; CANDE, W. Z. Mad2, Bub3, and Mps1 regulate chromosome segregation and mitotic synchrony in Giardia intestinalis, a binucleate protist lacking an anaphase-promoting complex. Molecular biology of the cell, v. 25, n. 18, p. 2774-2787, 2014.2 Disponível em: < http://www.molbiolcell.org/content/25/18/2774.short >. doi: 10.1091/mbc.E14-050975.

WANG, C.; LEES-MILLER, S. P. Detection and repair of ionizing radiation-induced DNA double strand breaks: new developments in nonhomologous end joining. International Journal of Radiation Oncology* Biology* Physics, v. 86, n. 3, p. 440-449, 2013. Disponível em: < http://www.sciencedirect.com/science/article/pii/S0360301613000746 >. doi: 10.1016/j.jirobp.2013.01.011.

WISEMAN, H.; HALLIWELL, B. Damage to DNA by reactive oxygen and nitrogen species: role in inflammatory disease and progression to cancer. Biochemical Journal, v. 313, n. Pt 1, p. 17, 1996. Disponível em: < https://www.ncbi.nlm.nih.gov/pmc/articles/PMC1216878/ >.

WOOD, R. D. Nucleotide excision repair in mammalian cells. Journal of Biological Chemistry, v. 272, n. 38, p. 23465-23468, 1997. Disponível em: < http://www.jbc.org/content/272/38/23465.short >. doi: 10.1074/jbc.272.38.23465.

WU, N.; YU, H. The Smc complexes in DNA damage response. Cell \&amp; bioscience, v. 2, n. 1, p. 1, 2012. Disponível em: < https://cellandbioscience.biomedcentral.com/articles/10.1186/2045-3701-2-5 >. doi: 10.1186/2045-3701-2-5.

ZHANG, Y. F., JIANG, R., LI, J. D., ZHANG, X. Y., ZHAO, P., HE, M. et al. SMC1A knockdown induces growth suppression of human lung adenocarcinoma cells through $\mathrm{G} 1 / \mathrm{S}$ cell cycle phase arrest and apoptosis pathways in vitro. Oncology letters, v. 5, n. 3, p. 749-755, 2013. Disponível em: < https://www.spandidospublications.com/10.3892/ol.2013.1116 > doi: 10.3892/ol.2013.1116.

ZHENG, G.; FU, Y.; HE, C. Nucleic acid oxidation in DNA damage repair and epigenetics. Chemical reviews, v. 114, n. 8, p. 4602-4620, 2014. Disponível em: < http://pubs.acs.org/doi/abs/10.1021/cr400432d >. doi: 10.1021/cr400432d.

ZHENG, X.-F.; KALEV, P.; CHOWDHURY, D. Emerging role of protein phosphatases changes the landscape of phospho-signaling in DNA damage response. DNA repair, v. 32, p. 58-65, 2015. Disponível em: < http://www.sciencedirect.com/science/article/pii/S1568786415001068 >. doi: 10.1016/j.dnarep.2015.04.014. 